\title{
Peranan Orangtua dalam Membina Kedisiplinan Anak
}

\author{
Yaman La Ndibo ${ }^{1}$, Wa Baru² \\ Universitas Muhammadiyah Kendari ${ }^{12}$ \\ Email Korespondensi: Yaman@umkendari.ac.id
}

\begin{abstract}
ABSTRAK: Tujuan penelitian ini adalah menelusuri peran orangtua dalam membina kedisiplinan anak. Informan dalam penelitian ini meliputi informan kunci, yaitu: orangtua anak di Desa Lanobake sebanyak 10 orang informan yang ditentukan secara purposive sampling. Teknik analisis data menggunakan pendekatan deskriptif kualitatif dengan interprestasi data yang diperoleh dari informan. Hasil penelitian ini menunjukkan bahwa peranan orang tua dalam membina kedisiplinan anak terdiri dari tiga bentuk. Adapun peranan yang dilakukan orang tua guna membina kedisiplinan anak yaitu diantaranya peranan orang tua sebagai pendidik, peranan orangtua sebagai motivator, peranan orang tua sebagai pengawas. Hasil penelitian mengungkap bahwa menerapkan peranan orang tua sebagai pendidik dilakukan dengan cara memberi bimbingan kepada anak agar selalu bersikaf positif, baik dalam lingkungan keluarga maupun di lingkungan masyarakat. Sedangkan peranan orang tua sebagai motivator dengan cara selalu memberikan semangat kepada anak, serta selalu memberikan pujian terhadap prestasi yang diraih anak, sehingga mereka menjadi semangat, terus disiplin, berprestasi, dan lain-lainnya. Peranan orang tua sebagai pengawas dengan cara mereka tidak memberikan kebebasan kepada anak dalam bergaul di lingkungan luar, serta tidak memberikan kesempatan kepada anak untuk menentukan arah hidupnya sendiri. Adapun hasil dari usaha pembinanaan kedisiplinan kepada anak yaitu seperti terbentuknya kesiplinan belajar, disiplin beribadah, disiplin bermain dan disiplin dalam bertindak.
\end{abstract}

Kata Kunci: Kedisiplinan Anak, Membina, Peranan orang tua

\begin{abstract}
ABSTACT: The purpose of this study was to explore the role of parents in fostering children's discipline. The informants in this study included 10 parents of children in Lanobake Village who were determined by purposive sampling. The data analysis technique used qualitative descriptive approach with data interpretation obtained from informants. The results of this study indicate that the role of parents in fostering children's discipline consists of three forms. The roles played by parents to foster children's discipline include the role of parents as educators, the role of parents as motivators, and the role of parents as supervisors. The results reveal that implementing the role of parents as educators is done by providing guidance to children so that they always have a positive attitude, both in the family environment and in the community environment. Meanwhile, the role of parents as motivators is by always giving encouragement to children, and always giving praise to children's achievements, so that they become enthusiastic, continue to be disciplined, achieve, and others. The role of parents as supervisors in a way that they do not give freedom to children in socializing outside, and do not provide opportunities for children to determine the direction of their own life. As for the results of efforts to develop discipline in children, such as the formation of learning discipline, worship discipline, discipline in play and discipline in acting.
\end{abstract}

Keywords: Child Discipline, Fostering, Parents' Role 


\section{PENDAHULUAN}

Keluarga merupakan pusat pendidikan yang pertama kali dan terpenting, karena sejak timbulnya adab kemanusiaan sampai kini, keluarga selalu mempengaruhi pertumbuhan budi pekerti tiap-tiap manusia. Di samping itu, orang tua dapat menanamkan benih kebatinan yang sesuai dengan kebatinannya sendiri ke dalam jiwa anak-anaknya. Inilah hak orang tua utama dan tidak bisa dibatalkan oleh orang lain. Sehubungan dengan ini, disiplin diri sangat diperlukan bagi anak agar ia memiliki budi pekerti yang baik. Bantuan yang diberikan oleh orang tua adalah lingkungan kemanusiawian yang disebut pendidikan disiplin diri. Karena tanpa pendidikan orang akan menghilangkan kesempatan manusia untuk hidup dengan sesamanya.

Perkembangan arus globalisasi saat ini sangat mudah bagi anak untuk terpengaruh kepada hal-hal negative khususnya pada anak-anak yang tingkatan pendidikannya masih rendah seperti pada tingkatan Sekolah dasar, pada umumnya anak diusia tersebut masih cenderung untuk melakukan hal-hal atau kegiatan-kegiatan yang mereka jumpai atau dilihatnya. Oleh karena itu sangat diperlukan peranan keluarga dalam mendidik kedisiplinan diri seorang anak, didalam menyiapkan anak, untuk mampu hidup mandiri, bertanggung jawab, dan disiplin ditengah masyarakat. Untuk itu diperlukan perhatian orang tua yang dimanifestasikan pada pola kepemimpinan terhadap anak dan dapat mendorong kemajuan anak didalam keluarga, sehingga tercipta keluarga yang sejahtera, bahagia dunia dan akhirat. Mengingat kondisi saat ini tingkat kedisiplinan anak sangatlah minim dan disiplin dalam beribadah pun sangat kurang jika tidak melalui panggilan atau perintah dari orang tuanya. Apalagi pada kenyataannnya masih banyak sekali orang tua yang disibukan dengan pekerjaan dan hal-hal lain dan masih banyak pendidikan akhlak keagamaan dan karakter orang tua masih kurang untuk diajarkan kepada anaknya.

Uraian tersebut dapat disimpulkan bahwa pihak yang harus berperan pertama kali dalam mewujudkan disiplin pada anak supaya tidak terbawa arus globalisasi adalah peran keluarga. Keluarga merupakan "Pusat Pendidikan" yang pertama dan utama dalam masyarakat, karena dalam keluargalah manusia dilahirkan. Bentuk, isi dan cara-cara pendidikan di dalam keluarga akan selalu mempengaruhi tumbuh dan berkembangnya budi pekerti dan kepribadian tiap-tiap manusia. Dengan demikian orang tua mempunyai tanggung jawab dalam membimbing dan mengarahkan agar anak berdisiplin baik dalam melaksanakan hubungan dengan Tuhan yang menciptakannya, dirinya sendiri, sesama manusia dan lingkungan alam dan makhluk hidup lainnya berdasarkan nilai moral. Namun pada kenyataannya, tidak semua keluarga dalam hal ini orang tua dapat melaksanakan peranannya dengan baik. Kenyataan tersebut dilatar belakangi oleh beberapa faktor salah satunya yaitu faktor pekerjaan. Orang tua lebih sering berada di luar rumah karena kesibukannya dalam bekerja, menjadikan perhatian dan kasih sayang pada anak berkurang. Kurangnya komunikasi yang terjalin antara orang tua dan anak menyebabkan kediplinan anak baik itu kedisiplinan dalam hubungnnya dengan Tuhan YME, dengan dirinya sendiri, maupun dengan orang lain menjadi kurang terkontrol oleh orang tuanya. Kenyataan tersebut dapat terjadi pada keluargakeluarga yang berada di perkotaan atau di perumahan yang sebagian besar orang tua sibuk dengan pekerjaannya. Hal tersebut menjadi sebuah problematika dalam membentuk kedisiplinan anak, anak akan cenderung untuk berbuat seenaknya sesuai keinginannya, dihubungkan dengan perkembangan modern saat ini akan mudah sekali mempengaruhi anak untuk 
melakukan hal-hal yang tidak diinginkan seperti apa yang didengar maupun dilihatnya baik melalui teman maupun media sosial.

Desa Lanobake merupakan salah satu Desa di Kecamatan Batukara, Kabupaten Muna yang merupakan desa tergolong maju terlihat dari jumlah penduduk, tingkat pendidikan serta kesejahteraan masyarakat yang tergolong cukup sejahtera. Sehingga adanya kondisi sosial tersebut, dengan mengingat pesatnya perkembangan teknologi saat ini serta pergaulan yang semakin modern sangat dikhawatirkan akan dengan mudah merusak nilai-nilai moralitas anak, apalagi jika keluarga memiliki kesibukan kerja sehingga waktu untuk mengontrol, mendidik anak sangat kurang, seperti halnya orang tua di Desa Lanobake memiliki kesibukan-kesibukan sebagai Pegawai Negeri Sipil (PNS), Nelayan, maupun petani. Kondisi tersebut akan mudah bagi anak untuk terjerumus dalam pergaulan-pergaulan negatif yang akan merusak dirinya sendiri serta meresahkan lingkungan bermasyarakat, dikarenakan adanya kesibukan dari orang tua mereka sehingga durasi waktu bersama anak sangat kurang.

Rumusan masalah pada penilitian ini yaitu bagaimanakah Peranan Orang Tua Dalam Membina Kedisiplinan Anak di Desa Lanobake Kecamatan Batukara, Kabupaten Muna.

\section{Konsep Peran Orang tua}

Kata peranan sebenarnya menunjukan pada aktifitas yang dilakukan seseorang untuk melakukan sesuatu dalam suatu kelompok masyarakat. Apabila seseorang tidak melakukan apa-apa dalam suatu kelompok tersebut maka ia tidak akan melakukan hak dan kewajibannya sebagai anggota dalam organisasi.

Secara Etimologis kata peranan berasal dari kata peran yang artinya: pemain sandiwara, tukang lawak. Kata "Peran" diberikan akhiran "an" maka menjadi peranan yang artinya sesuatu yang memegang pimpinan terutama atau karena hal atau peristiwa. Peranan adalah sesuatu yang, bagian atau yang memegang pimpinan yang terutama dalam terjadinya sesuatu hal dan peristiwa. Pengertian ini menunjuk pada suatu sosial tertentu, baik secara sepintas maupun berlangsung lama atau tetap yang didalamnya terdapat seseorang atau beberapa orang yang bertindak atau berperan sebagai kepala atau pemimpin terhadap kelompoknya (Poerwadarminta, 2006:735).

\section{Peranan Orang Tua dalam Pendidikan}

Peranan Ibu dalam Pendidikan

Keluarga adalah wadah pertama dan utama bagi pertumbuhan dan perkembangan anak. Peranan ibu dalam keluarga amat sangat penting. Peran ibu, yaitu memberikan rasa kasih sayang dan memberi rasa aman kepada anak (Zakiah Darajat, 1995:49). Anak tidak hanya mempunyai kebutuhan jasmani saja, akan tetapi ia juga mempunyai kebutuhankebutuhan kejiwaan yang menentukan perkembangan selanjutnya.

Peranan Ayah dalam Pendidikan

Ayah berperan penting dalam perkembangan anaknya secara langsung. Mereka dapat membelai, mengadakan kontak bahasa, berbicara, atau bercanda dengan anaknya. Semuanya itu akan sangat mempengaruhi perkembangan anak selanjutnya. Ayah juga dapat mengatur serta mengarahkan aktivitas anak (Save M. Dagun, 2013:15). Misalnya, menyadarkan anak bagaimana menghadapi lingkungannya dan situasi di luar rumah. la memberi dorongan, membiarkan anak mengenal lebih banyak, melangkah lebih jauh, menyediakan perlengkapan permainan yang menarik, mengajar mereka membaca, mengajak anak untuk memperhatikan kejadian-kejadian dan halhal yang menarik di luar rumah, serta mengajak anak berdiskusi. Semua tindakan 
ini adalah cara ayah (orang tua) untuk memperkenalkan anak dengan lingkungan hidupnya dan dapat mempengaruhi anak dalam menghadapi perubahan sosial dan membantu perkembangan kognitifnya di kemudian hari.

Sikap bijaksana diperlukan untuk mengerti kemampuan anak, kekurang tahuan terhadap kemampuan anak terkadang menumbuhkan sikap kasar terhadap anak. Sikap kasar akan bertambah persoalannya bahkan bimbingan yang diberikan terhadapnya justru menjadi tekanan jiwa dalam dirinya.

\section{Macam-Macam Pola Asuh}

Dalam mengasuh dan membina anak, masyarakat kita mengenal tiga model pola asuh yaitu:

\section{a. Pola Asuh Otoriter}

Dalam pola asuh yang otoriter biasanya pihak orang tua yang menggariskan keputusan-keputusan tentang perilaku anak-anaknya. Wujudnya tampak dalam contoh berikut ini "Kamu harus bangun pagi jika saya mengatakan kamu harus bangun. Kamu harus pergi tidur jika saya menyatakan kamu harus pergi tidur" (Maurice Balson, 1987:2).

Pola asuh ini bercirikan dengan adanya aturan-aturan yang kaku dari orang tua. Kebebasan anak dibatasi oleh orang tua, sehingga aturan yang ada dalam pergaulan keluarga terasa kaku sebab orang tua selalu memaksakan untuk berperilaku sesuai dengan keinginan orang tua. Bila aturan-aturan yang berlaku dilanggar, orang tua akan memberi hukuman kepada anaknya, namun jika akan mematuhinya orang tua tidak memberikan hadiah atau pujian karena apa yang dilakukan anak sudah sepantasnya dilakukan.

Dapat ditarik suatu kesimpulan bahwa pola asuh otoriter adalah orang tua sebagai pemegang kekuasaan tertinggi dalam keluarga untuk mengekang dan mengendalikan anak. Kebebasan anak dibatasi oleh orang tua, sehingga aturan yang ada dalam pergaulan keluarga terasa kaku. Bila aturan-aturan yang berlaku dilanggar, orang tua tidak segan-segan akan memberi hukuman kepada anaknya.

\section{b. Pola Asuh Permisif}

Dalam pola asuh permisif atau juga dikenal dengan pola asuh liberal, keluarga memberikan kebebasan pada anak, kebebasan diberikan dari orang tua kepada anaknya untuk berperilaku sesuai dengan keinginan keinginan anak. Orang tua kurang peduli dan tidak pernah memberi aturan yang jelas dan pengarahan pada anak. Segala keinginan anak keputusannya diserahkan sepenuhnya pada anak, orang tua tidak memberikan pertimbangan bahkan tidak tahu atau sikap orang tua yang masa bodoh, anak kurang tahu apakah tindakan yang dikerjakan salah atau benar (Yatim, 1986: 96).

Dari uraian yang dikemukakan di atas, dapat disimpulkan bahwa pola asuh permisif adalah orang tua yang memberikan kebebasan pada anak untuk berbuat sekehendak hatinya. Keputusan diserahkan sepenuhnya pada anak, orang tua tidak memberikan pertimbangan apakah tindakan yang ia kerjakan salah atau benar.

\section{Pola Asuh Demokratis}

Pola asuh demokratis mendorong anak sebagai individu yang selalu berkembang, sehingga memiliki ciri adanya sikap saling terbuka antar anak dengan orang tua. Dalam setiap pengambilan keputusan atau aturan-aturan yang dipakai atas kesepakatan bersama. Orang tua memberi kesempatan pada anak untuk menyampaikan pendapat, gagasan maupun keinginannya dan belajar untuk dapat menghargai dan menanggapi orang lain. Orang tua bersikap hanya sebagai pemberi pendapat dan pertimbangan terhadap aktivitas anak (Yatim, 1986: 98). 
Menurut Martaniah (1964:19), orang tua demokratis besar pengertiannya terhadap anak dan memberikan kebebasan kepada anak untuk menyatakan pendapatnya. Bagi orang tua demokratis anak mempunyai kedudukan yang sama dalam keluarga. Orang tua yang demokratis selalu memperhatikan perkembangan anak, dan tidak harus sekedar mampu dalam memberi saran-saran atau nasehat saja, tetapi juga mau mendengarkan keluhan anak sehubungan dengan persoalan yang anak hadapi.

Tim Penggerak PKK Pusat (1992:10) menjelaskan, pelaksanaan pola asuh demokratis atau yang dikenal dengan pola asuh pendekatan perilaku, tidak menang dan tidak kalah adalah orang tua yang bersikap keras, jelas dan konsekuen, tidak memaksakan kehendak, menghargai dan menghormati, membiasakan minta maaf kepada anak jika akan, sedang dan sesudah menyinggung perasaan orang lain, kalau anak menyimpang dari aturan, adat, hukum dan agama, menasehati tanpa merendahkan martabat anak, tidak menyalahkan atau membenarkan apabila salah satunya berkelahi, menghindari, mengalahkan atau memenangkan anak. Akibat dari pola asuh ini adalah menyebabkan anak menjadi mandiri, mempunyai tanggung jawab, mempunyai inisiatif dan kreatif, sopan santun dan dapat membedakan yang baik dan yang buruk. Jadi dapat ditarik suatu pengertian bahwa pola asuh demokratis adalah orang tua memposisikan anak dalam posisi yang sama dengan orang tua artinya memiliki hak dan kewajiban yang sama, orang tua tidak harus menang dan tidak harus kalah artinya orang tua bersikap keras, jelas dan konsekuen tetapi memaksakan kehendak. Orang tua memberi kesempatan pada anak untuk menyampaikan pendapat, gagasan maupun keinginannya dan belajar untuk dapat menghargai dan menanggapi oarang lain. Orang tua bersikap hanya sebagai pemberi pendapat dan pertimbangan terhadap aktivitas anak. Anak akan semakin termotivasi dalam melakukan kegiatan karena adanya kepercayaan diri yang diberikan oleh orang tua, sehingga semakin bertanggung jawab.

\section{Pola Asuh Penelantar}

Pola asuh tipe yang terakhir adalah tipe penelantar. Orang tua tipe ini pada umumnya memberikan waktu dan biaya yang sangat minim pada anak-anaknya. Waktu mereka banyak digunakan untuk keperluan pribadi mereka, seperti bekerja, dan juga kadangkala biayapun dihemathemat untuk anak mereka. Termasuk dalam tipe ini adalah perilaku penelantar secara fisik dan psikis pada ibu yang depresi. Ibu yang depresi pada umumnya tidak mampu memberikan perhatian fisik maupun psikis pada anak-anaknya. Beberapa macam pola asuh orangtua terhadap anaknya semua mempunyai pengaruh yang berbeda.

\section{Konsep Kedisiplinan Anak}

Menurut kamus kata "Disiplin" memiliki beberapa makna di antaranya, menghukum, melatih, dan mengembangkan kontrol diri sang anak. Menurut Gootman, Seorang ahli pendidikan dari Universitas of Georgia di Athens, amerika Nizar (2009: 22), berpendapat bahwa "disiplin akan membentuk anak untuk mengembangakan kontrol dirinya, dan membantu anak mengenali perilaku yang salah lalu mengoreksinya". Tujuan dari disiplin adalah bukan hukuman, tetapi memberikan pelajaran kepada anak untuk bertanggung jawab terhadap apa yang telah dilakukan dan bagaimana akibat perilaku itu terhadap orang lain.

Disiplin berasal dari bahasa latin Discere yang berarti belajar (Subur, 2015: 297). Dari kata ini muncullah kata Disciplina yang berarti pengajaran atau pelatihan. Dalam penggunaannya kata disiplin mengalami perkembangan makna ke dalam 
dua pengertian. Pertama, disiplin diartikan sebagai kepatuhan terhadap peraturan, tatanan, norma, atau tunduk pada pengawasan, dan pengendalian. Kedua, disiplin sebagai latihan, pembiasaan yang bertujuan mengembangkan diri agar terbiasa berperilaku tertib. Disiplin ialah tindakan yang menunjukkan perilaku tertib dan patuh pada berbagai ketentuan danperaturan (Muhammad \& Kusumaning, 2016: 192). Makna dasar disiplin ialah tertib (Edi \& Chaerul, 2009:9). Dalam pengertian yang lebih luas, disiplin sama maksudnya dengan kepatuhan atau ketaatan terhadap semua aturan dan tatanan yang dijunjung tinggi oleh masyarakat.

\section{METODE PENELITIAN}

Pemilihan informan ditentukan dengan cara purposive sampling yaitu memilih informan dengan sengaja oleh penulis dengan mempertimbangkan bahwa informan tersebut dapat memberikan informasi tentang peran orang tua dalam membina kedisiplinan anak. Pada penelitian ini yang akan dijadikan subjek penelitian adalah masyarakat yang telah berkeluarga di Desa Lanobake yang merupakan informan kunci pada penelitian ini. Adapun informan tersebut yaitu ibu Nurdiah, S.Pd, Wa Ode Sarfiah, S.Pd, Bapak Maat, Muh. Kasim, La Hatia, Sumardi, La Ode Fanali, Amiruddin, Aldin, La Tandu. Informan kunci merupakan informan yang mengetahui secara persis terkait dengan informasi yang dibutuhkan peneliti dalam hal ini orang tua anak.

Teknik pengumpulan data dalam penelitian ini dilakukan dengan penelitian lapangan (Field Work) yaitu pengumpulan data secara langsung dilapangan guna memperoleh data yang akurat, sebagaimana yang dikatakan oleh Sugiyono (2003: 23) teknik pengumpulan data merupakan langkah yang paling strategis dalam penelitian, karena tujuan utama dari penelitian adalah mendapatkan data.
Adapun metode yang digunakan: observasi, wawancara (interview), dan dokumentasi

\section{HASIL PENELITIAN DAN PEMBAHASAN}

Setiap orang tua mempunyai kesepahaman yang sama bahwa orang tua merupakan kunci utama dalam penerapan kedisiplinan anak sejak dini. Disiplin pada anak merupakan salah satu aspek yang perlu ditanamkan dan dikembangkan sedini mungkin pada diri anak, sehingga mereka tidak mengalami kesulitan dalam memasuki usia remaja. Orang tua memiliki peranan dalam lingkungan keluarga, dan tidak dapat diberikan dilembaga pendidikan. Peran orang tua dalam menanamkan sikap disiplin dapat dilakukan dengan tiga hal, pertama mendorong anak untuk belajar hal-hal positif, kedua Mengarahkan perhatian anak untuk mengolah pengaruh yang positif, ketiga kesan positif yang diperoleh anak dari hasil belajarnya. Di samping tiga hal tersebut, orang tua harus menciptakan kondisi lingkungan keluarga yang harmonis yang memungkinkan anak dapat mengembangkan disiplin dirinya.

Beberapa hal yang dapat dilakukan orang tua agar anak berperilaku disiplin adalah pertama membuat aturan-aturan yang sederhana, kedua memberi alasanalasan sederhana mengapa orangtua tidak bisa menerima perilaku tertentu, ketiga memberi pilihan yang terbatas terhadap anak-anak, dan keempat menjadi contoh yang baik bagi anak. Oleh karena itu, agar orang tua dapat berperan dalam menerapkan pola asuh anak, orang tua haruslah memiliki pengetahuan. Apabila orangtua dapat memahami pola asuh yang mana dapat di terapkan dan mengetahui dampaknya, maka sadar atau tidak sadar, orangtua dapat segera merubahnya. Jangan sampai orang tua menerapkan pola asuh yang salah asuh dalam mendidik anak. Mendidik merupakan perwujudan rasa tanggungjawab orang tua terhadap anak. 
Selain pengetahuan orang tua juga harus mengetahui karakteristik yang dimiliki oleh anak seutuhnya.

Pemahaman tentang pengetahuan kedisiplinan ini menuntut orang tua untuk mengerti apa yang diharapkan oleh anakanaknya. Orang tua yang baik, akan selalu melakukan segala yang dapat menumbuhkan kemampuan anak untuk bertata kelakuan yang baik dan sesuai etika keluarganya. Seperti yang diungkapkan Ibnu Nizar (2009:22) bahwa disiplin akan membantu anak itu untuk membangun kontrol dirinya, dan membantu anak mengenali perilaku yang salah lalu mengoreksinya. Orang tua dalam menanamkan disiplin pada anak dalam setiap keluarga berbeda-beda. Begitu juga dengan pola asuh orang tua dalam memberikan aturan-aturan dan pendidikan terhadap anak-anaknya selalu berbedabeda berdasarkan latar belakang pengasuhan orang tua itu sendiri, sehingga akan menghasilkan bermacam-macam pola asuh yang berbeda. Adanya berbagai macam pola pengasuhan orang tua ini, tentunya tidak sama antara orang tua satu dengan yang lain. Perbedaan profesi berpengaruh terhadap pola asuh yang diberikan orang tua terhadap anaknya. Ada yang menerapkan pola asuh yang tepat dan tetap intensif dalam mendidik anaknya demi perkembangan potensi anaknya, tetapi ada juga orang tua yang kurang memperhatikan anaknya dikarenakan sibuk dengan pekerjaanya yang tidak bisa ditinggalkan. Dari perbedaan pola asuh orang tua yang berprofesi sebagai ibu rumah tangga dan pekerja tersebut memunculkan berbagai macam ploblem terhadap perkembangan bakat yang dimiliki anak-anak. Misalnya ketika orang tua disibukkan dengan pekerjaannya dan tidak bisa mengasuh serta tidak bisa memberikan pendidikan kepada anaknya dengan baik, maka bakat anak tidak akan bisa berkembang dengan baik. Kemudian ketika orang tua tidak mendukung bakat yang dimiliki anak, maka anak akan merasa terkekang dengan keputusan dan pilihan dari orang tua.

Disiplin merupakan kepatuhan untuk menghormati dan melaksanakaan suatu sistem yang mengharuskan orang untuk tunduk kepada keputusan, perintah dan peraturan yang berlaku. Dengan kata lain disiplin adalah sikap menaati peraturan dan ketentuan yang telah ditetapkan tanpa pamrih (Naim, 2012). Hal ini selaras dengan yang diungkapkan oleh Mulyasa (2008) dan The Liang Gie (dalam Imron, 2011) bahwa disiplin merupakan suatu keadaan tertib dimana orang-orang yang bergabung dalam suatu organisasi tunduk pada peraturan yang telah ada dengan senang hati. Sedangkan Kedisipilinan memiliki makna diantaranya yaitu penertiban dan pengawasan diri, penyesuaian diri terhadap aturan, kepatuhan terhadap perintah pimpinan, penyesuaian diri terhadap norma-norma kemasyarakatan dan lainlain.

Berdasarkan hasil penelitian yang telah dilakukan terkait dengan peranan orang tua dalam membina kedisipilan anak di Desa Lanobake, Kecamatan Batukara, Kabupaten Muna dengan fokus penelitian yaitu untuk mengetahui bagaimana peranan orang tua sebagai pendidik anak, peranan orang tua sebagai pemberi motivasi terhadap anak dan peranan orang tua sebagai pengawas anak.

Peran orang tua sebagai pendidik merupakan hal yang paling utama yang harus diterapkan oleh orang tua kepada anak, sebelum anak mengenal dunia pendidikan orang tua mempunyai kewajiban untuk mengenalkan terlebih dahulu kepada anak terkait dengan hal-hal yang baik dan positif kepada anak sehingga anak menjadi sosok yang memiliki kepribadian yang baik. Selain itu juga penerapan disiplin terhadap anak jika dilakukan sedini mungkin akan menimbulkan dampak positif terhadap anak itu sendiri. Hasil penelitian 
menunjukkan bahwa peranan orang tua anak di Desa Lanobake dilakukan dengan selalu melakukan mentoring kepada anak serta memberikan motivasi yang positif dan mengajarkan anak untuk taat terhadap berbagai aturan-aturan yang berlaku baik dalam lingkungan rumah maupun lingkungan diluar rumah. Hal ini dilakukan orang tua di Desa Lanobake dengan tujuan untuk bagaimana anak dapat terbentuk karakter yang disiplin sebagai bentuk pengalaman/kebiasaan yang dapat diterapkan kedepannya ketika anak telah beranjak dewasa.

Peranan orang tua sebagai pemberi motivasi/pendorong, sebagai orang tua juga sangat perlu melakukan motivasi kepada anaknya, agar anak menjadi semangat dan percaya diri untuk menghadapi setiap masalah yang dia jumpai didalam lingkungan rumah maupun diluar rumah. Hasil penelitian menunjukkan bahwa peranan orang tua anak yang dilakukan orang tua di Desa Lanobake yaitu dengan memberikan semangat kepada anak untuk selalu membentuk sikap disiplinnya seperti waktu belajar, ibadah dan bermain, selain itu juga dilakukan dengan memberikan pujian kepada anak dengan prestasi yang diraih oleh anak agar anak tetap semangat untuk mengembangkan potensi yang ada didalam dirinya dan memberikan kebebasan kepada anak untuk berekspresi sesuai dengan kemampuan yang dimilikinya.

Peranan orang tua sebagai pengawas merupakan kewajiban orang tua untuk melihat dan mengawasi anak agar tidak keluar dari kegiatan yang menyimpang, terutama dari pengaruh lingkungan baik dari lingkungan keluarga, sekolah maupun lingkungan masyarakat. Hasil penelitian menunjukkan bahwa peranan yang dilakukan orang tua anak di Desa Lanobake, Kecamatan Batukara dalam membina kedisiplinan anak sebagai wujud dari peranan orang tua sebagai seorang pengawas terhadap anak-anaknya, dalam melakukan pengawasan kepada anak dilakukan dengan mengontrol kegiatan anak baik dalam lingkungan rumah maupun lingkungan diluar rumah, selain itu juga orang tua melakukan pelarangan kepada anak untuk tidak membiasakan diri untuk keluar dimalam hari dan juga mengontrol anak agar tidak terbiasa menentukan arah hidupnya sendiri.

Adapun keberhasilan orang tua dilihat dari seberapa berhasilnya orang tua dalam menanamkan nilai-nilai kedisiplinan kepada anak, hal ini seperti yang telah dilakukan orang tua didesa lanobake dalam membina kedisiplinan kepada anak sebagai wujud dari peran mereka sebagai orang tua. Hasil daripada usaha pembinanaan kedisiplinan kepada anak yaitu seperti terbentuknya kesiplinan belajar, disiplin beribadah, disiplin bermain dan disiplin dalam bertindak.

Disiplin waktu belajar merupakan tindakan disipliner kepada anak oleh orang tua, dimana anak harus mampu membiasakan dirinya untuk selalu tepat waktu dalam melakukan kegiatan belajar baik waktu belajar pada saat dilingkungan sekolah maupun waktu belajar dilingkungan rumah. Seperti contoh tepat waktu dalam mengerjakan tugas yang diberikan oleh guru disekolah. Oleh karena itu peranan orang tua sangat dibutuhkan dalam menumbuhkan disiplin belajar anak karena waktu belajar merupakan hal yang sangat fundamental untuk membentuk anak yang cerdas dimasa depan.

Disiplin waktu beribadah yang dimaksud dalam hal ini yaitu orang tua senantiasa mengingatkan kepada anak untuk senantiasa beribadah dengan peraturan-peraturan yang terdapat didalamnya. Disiplin waktu beribadah harus selalu disampaikan kepada anak karena merupakan hal dasar yang harus melekat pada diri anak itu sendiri. Oleh karena itu orang tua harus terus menerus mengingatkan kepada anak untuk selalu 
menanamkan pada dirinya hal-hal kebaikan.

Disiplin waktu bermain yang dimaksud yaitu anak harus tahu bagaimana mengatur dan menempatkan waktu dimana harus bermain, misalnya setelah mengerjakan seluruh tugas baik tugas sekolah, tugas membantu orang tua dirumah. Oleh karenanya orang tua juga harus mengatur waktu-waktu dimana anak boleh bermain.

Disiplin dalam bertindak artinya anak harus mengetahui secara persis dengan keputusan tindakan yang dibuatnya agar tindakan tersebut dapat bernilai negatif baik bagi dirinya maupun bagi lingkungan disekitarnya. Contohnya memilih teman bermain serta menentukan arah hidupnya sendiri. Dalam hal disiplin dalam bertindak orang tua harus selalu melakukan pengawasan kepada anak, agar anak tidak terjerumus dengan perbuatannya.

\section{SIMPULAN}

Berdasarkan hasil dan pembahasan maka dapat ditarik kesimpulan bahwa dalam membina kedisiplinan anak di Desa Lanobake, Kecamatan Batukara sangat dibutuhkan peranan orang tua adapun, bentuk peranan yang dilakukan yaitu Peranan sebagai pendidik, dilakukan dengan selalu memberikan bimbingan kepada anak untuk selalu bersikap positif baik dalam lingkungan keluarga maupun dilingkungan masyarakat. Peranan sebagai pemberi motivasi dilakukan orang tua di Desa Lanobake dengan cara memberikan semangat kepada anak untuk selalu menerapkan kedisiplinan dalam diri anak dan memberikan pujian terhadap prestasi yang diraih oleh anak dengan tujuan agar anak tetap semangat dalam meraih setiap prestasinya. Peranan sebagai pengawas dilakukan dengan tidak memberikan kekebasan kepada anak baik dalam bergaul maupun dalam menetukan pilihan hidupnya. Adapun bentuk disiplin yang telah diterapkan kepada anak yaitu disiplin waktu belajar, disiplin dalam beribadah, disiplin waktu bermain dan disiplin dalam bertindak.

\section{UCAPAN TERIMA KASIH}

Artikel ini dapat diselesaikan berkat kerjasama semua penulis. Kami menyadari jika artikel ini dibuat atas partisipasi banyak pihak, untuk itu penulis mengucapkan banyak terima kasih kepada semua orang yang telah ikut berkontribusi. Ucapan terima kasih juga peneliti berikan kepada editor Journal of Education and Teaching (JET), Fakultas keguruan dan ilmu pendidikan, Universitas muhammadiyah kendari yang siap menyediakan media, dan telah memberikan saran, masukan, dan pelayanan untuk kesempurnaan artikel ini

\section{DAFTAR PUSTAKA}

Andi, Prastowo. (2012). Panduan Kreatif Membuat Bahan Ajar Inovatif. Yogyakarta: Diva Press.

Baron, R.A dan Byrne, D. (2003). Psikologi Sosial. Edisi Kesepuluh. Jilid 2. Jakarta: Erlangga.

Balson, Maurice. (1987). Bagaimana Menjadi Orang Tua Yang Baik. Jakarta: Bumi Aksara.

Dagun, Save M. (2013). Psikologi Keluarga (Peranan Ayah dalam Keluarga). Jakarta: PT Rineka Cipta.

Danny I Yatim. (1986). Kepribadian, Keluarga dan Narkotika. Jakarta: Ancan.

Edi \& Chaerul. (2009). Membangun Disiplin dalam Mendidik. Bandung: CV. Putra

Indah, Pertiwi. (2010). Penerapan Role Playing dalam meningkatkan hasil belajar anak. Skripsi. Tidak dipublikasikan.

Munir, Zaldy. (2010). Peran dan Fungsi Orang Tua dalam Mengembangkan Kecerdasan Emosional Anak. Tersedia: http://zaldy.wordpress.com.2010. 
Martaniah Mulyani. (1964). Peranan Orang Tua dalam Perkembangan Kepribadian.Yogyakarta: Jiwa Baru.

Ngalim, Purwanto. (2006). Psikologi Pendidikan. Bandung: Rosda Karya.

Nizar, Imam Ahmad. (2009). Membentuk dan Meningkatkan Disiplin Anak sejak ini. Yogyakarta: Diva Press.

Poerwadarminta, W.J.S. (2006). Kamus Umum Bahasa Indonesia. Jakarta: Balai Pustaka.

Sobur, Alex. (2015). Komunikasi Orang Tua dan Anak. Bandung: Angkasa.

Soegeng Prijodarminto. (2000). Disiplin Kiat Menuju Sukses. Jakarta: Pradiya Paramita.

Soerjono, Soekanto. (2007). Sosiologi Suatu Pengantar. Raja Grafindo Persada. Jakarta.

Sugiyono. (2011). Metode Penelitian Kuantitatif, Kualitatif dan R\&D. Bandung. Alfabeta.

Suhendi, Hendi \& Ramdani Wahyu. (2001). Pengantar Studi Sosiologi Keluarga. Bandung: Pustaka Setia.

Syafrudin. (2015). Penyuluhan Kesehatan Pada Remaja, Keluarga, Lansia dan Masyarakat. Jakarta: Trans Info Media.

Tim Penggerak PKK Pusat. (1992). Pedoman Pola Asuh Anak Dalam Keluarga. Jateng. 